Working Paper 08/2010

9 December 2010

\title{
Are House Prices Rising Too Fast in China?
}

Prepared by Ashvin Ahuja, Lillian Cheung, Gaofeng Han, Nathan Porter and Wenlang Zhang*

Research Department of Hong Kong Monetary Authority Asia-Pacific Department of International Monetary Fund

\begin{abstract}
Sharp increase in house prices combined with the extraordinary lending growth in Mainland China during 2009 has led to concerns of an emerging real estate bubble. We find that, for China as a whole, the current levels of house prices do not seem significantly higher than would be justified by underlying fundamentals. However, there are signs of overvaluation in some cities' mass-market and luxury segments. Unlike advanced economies before 2007-8, prices have tended to correct frequently in China. Given persistently low real interest rates, lack of alternative investment and mortgage-to-GDP trend, rapid property price growth in China has, and will continue to have, a structural driver.
\end{abstract}

JEL Classification: E21, E22, G12

Keywords: House price, price misalignment, financial stability, leverage cycle Authors’ E-Mail Addresses: aahuja@imf.org, lcheung@hkma.gov.hk, ghan@hkma.gov.hk, nporter@imf.org, and wzhang@hkma.gov.hk

The views and analysis expressed in this paper are those of the authors, and do not necessarily represent the views of the Hong Kong Monetary Authority or the International Monetary Fund.

* The authors would like to thank Nigel Chalk, Dong He, Papa N'Diaye, Haibin Zhu as well as seminar participants at the People's Bank of China and the Hong Kong Monetary Authority for helpful comments. Discussion with Nigel Chalk substantially improved the paper. We thank Daniel Law, Ozge Turan and Imel $\mathrm{Yu}$ for able research and editorial assistance. 


\section{Executive Summary:}

- Sharp increases in property prices on the Mainland have ignited concerns over the sustainability of the real estate sector and worries about the adverse impact of potential property price adjustments on the Mainland economic growth, and monetary and financial stability. This paper first uses two approaches to assess possible property price misalignment in China and then discusses the impact of possible property price adjustments on China's domestic demand, banking sector and local government revenue.

- On degree of price misalignment, we find that, as of mid-2010, house prices are not significantly overvalued in China as a whole. However, the mass-market segment in a number of coastal cities-but most clearly in Shanghai and Shenzhen - as well as a few inland cities may be in the early stages of excessive price growth. Early signs of price misalignment can also be detected in the luxury segment in Beijing and Nanjing. Secondly, we find that over the past decade, when misalignments in house prices have occurred, they have been corrected relatively quickly. This constant correction of house prices is unlike the behaviour observed in several industrial economies before 2008, where deviations from benchmark prices tended to persist far longer, allowing for an accumulation in vulnerabilities, ending in a large and abrupt adjustment.

- Going forward, China's property markets will continue to have an underlying propensity for rapid price growth owing to structurally low real interest rates which are combined with rapid income and productivity growth, the lack of property tax, increasing availability of mortgage financing, and insufficient alternative investment vehicles.

- While property price adjustments would not affect China's private consumption significantly due in part to limited wealth effect, they could exert non-negligible impacts on China's investment (particularly in cities that have seen high real estate investment) and local government revenue. Banking sector's direct exposure to the property market looks manageable, but its total exposure is larger owing to the strong linkages between real estate sector and other industries. 


\section{INTRODUCTION}

During 2009, China's residential property market prices turned around and grew rapidly, especially in several large- and medium-sized cities, as the impact of the global financial crisis subsided and domestic financial conditions relaxed. Price-to-rent ratios rose to new highs, raising concerns about the sustainability of this property market price dynamic. In addition, price-income ratios also started to rise, reversing the declining trend that had been in place since the middle of the decade. These developments have led many to question the sustainability of these price increases, and made housing affordability a prominent social and political issue.

This paper compares movements in China's residential property prices with those implied by market fundamentals. We take two different approaches to measure benchmark prices. The first is based on a panel regression linking prices to long-term fundamentals and the second relies on the relationship between price, rent, and ownership cost. $^{1}$ We then use the latter measure to characterise price deviations in comparator countries as well as discuss similarities and differences with China's experience. Overall, we find that while prices have run ahead of fundametals in some market segments, nationally this does not seem to be the case. Moreover, when compared to property markets in other countries, pricing misalignments in China seem to be relatively short-lived although, again, not in all market segments. Finally, we discuss briefly a set of policies that could help contain imbalances in China's housing market going forward.

The main findings of the paper are:

- First, on degree of price misalignment, we find that, as of mid-2010, house prices are not significantly overvalued in China as a whole. However, the mass-market segment in a number of coastal cities — but most clearly in Shanghai and Shenzhen as well as a few inland cities may be in the early stages of excessive price growth. Early signs of price misalignment can also be detected in the luxury segment in Beijing and Nanjing.

- Secondly, we find that over the past decade, when misalignments in house prices have occurred, they have been corrected relatively quickly. Deviation from benchmark prices appear not to be persistent with a half life of around one quarter on average for overall China; less than the cases of Hong Kong SAR (two to four quarters) and Singapore (five quarters). This constant correction of house prices is unlike the behaviour observed in several industrial economies before 2008 - especially the U.S., New Zealand, and France - where deviations from benchmark prices tended to persist

\footnotetext{
${ }^{1}$ We are aware of one other paper with a focus on China's house price misalignment; that is, Wu, Gyourko, and Deng (2010).
} 
far longer, allowing for an accumulation in vulnerabilities, ending in a large and abrupt adjustment.

- Thirdly, the policy measures taken by the Mainland Government in April 2010 appear to have had some impact on price growth. The gaps between market and fundamentals-implied prices have become smaller in a few cities. However, in a few cities, these market and policy measures do not seem to have been very effective in bringing prices back toward fundamentals. In particular, pices in the mass market segments in Guangzhou, Tianjin and Shenzhen recently seem to have remained persistently misaligned.

Because the benchmark in the asset pricing approach is linked to market rent and a set of fundamental factors, this measure of price deviation should give us an early warning indicator of market exuberance that we can compare across cities and over time. However, it should be noted that while this measure can capture house price behaviour that may not be consistent with equilibrium, it is only a sufficient (and not necessary) condition for detecting a misalignment from fundamentals in housing markets. In many cases, serious misalignment only really becomes apparent after a substantial and typically abrupt price decline. Nonetheless, our measure of misalingment has identified several historical episodes outside China, including the Hong Kong SAR during 1997 and in several advanced markets more recently.

Two China-specific developments - recent growth in housing mortgages and the importance of property in total investment-have elevated concerns over the potential impact a significant housing price correction might have on overall economic and financial activity. On the financing side, real estate loan growth in 2009 reached an all-time high, although this reflects development of the new mortgage market. Mortgage loan growth was nearly 50 per cent, raising mortgage debt from 10 to around 15 per cent of nominal GDP in one year. By late 2009, loans to property developers and mortgages together accounted for about 20 per cent of total loans, which sharply increased bank exposure to property. While the overall financial development suggested by the growth of the mortgage market is welcome, the newly important leverage factor in the market warrants careful supervision (as discussed in Section III). On the activity side, real estate investment now accounts for about 20 per cent of total investment and around 9 per cent of GDP, is a major source for China's economic growth. Land sales have also become an important source of revenue for local governments. In Beijing and Zhejiang, for example, land sales accounted for as much as 30 per cent of government general revenue in 2009. Despite its growing importance to the real economy we find housing prices have had a somewhat limited impact on consumption. Nonetheless, it could have notable impact on private investment and local government revenue, particularly in cities that have seen high real estate investment. The growing importance of property in real activity and an increasing exposure of the banking sector to the real estate markets highlight the 
importance of using early warning measures of misalignment, like the one we develop, and the potential impacts will only grow over time.

Given the awareness of Mainland authorities of the risks of excessive property price growth and their experience in containing them, the likelihood of financial instability precipitated by a housing price bust seems small. ${ }^{2}$ However, China's property markets will continue to have a strong underlying propensity for rapid price growth owing to structurally low real interest rates (which are combined with rapid income and productivity growth), the lack of property tax, increasing availability of mortgage financing, and insufficient alternative investment vehicles.

While we do not see evidence of significant and broad-based overvaluation in China residential property prices today, imbalances take time to build and may also take time to be clearly revealed. In China, allowing real interest rates to rise and respond more flexibliy to macroeconomic conditions, having a meaningful property tax, and carefully monitoring and then reacting to rising leverage would go a long way to limit the propensity for property price inflation. Such policies do carry some risk of asset price volatility as the housing market adjusts. However, failing to do so will increase the risks of a larger disconnect between asset prices and the underlying fundamentals. In addition, maintaining tight prudential standards, active monitoring of leverage, and robust financial sector supervision will all be necessary to limit the risks posed by potential property price bubbles.

The paper starts by presenting salient facts about property market developments and concerns in Section II. It then outlines an empirical strategy to assess house price misalignment as well as displays characteristics of the measured misalignment in known cases of "housing bubbles" in Section III. Section IV investigates whether housing prices are overvalued in China's cities. Finally, Section V fleshes out key policy requirement to prevent financial imbalances from taking hold with conclusion in Section VI.

\section{Salient Features of the Mainland Property Market}

China's private residential property market is relatively new, having existed for less than two decades. During 2004 - 09, overall property prices in 35 cities, as reported by the National Development and Reform Commission (NDRC), had approximately doubled. Meanwhile, National Bureau of Statistics (NBS)-reported prices

2 Indeed, measures announced in April 2010 are designed to face this challenge. They include increase in down-payment ratio for first and second home purchases, restoring the mortgage interest rate to 1.1 times the benchmark lending rate for second home purchases, rejecting third purchase home mortgage applications, as well as suspending real estate sales to non-locals. Discussion is also growing about a potential implementation of property tax on real estate. 
in 70 cities have increased by 31 per cent during the same period ${ }^{3}$ (Fig. 1). These national average price data tend to understate the property price inflation in major cities.

House prices were on a rising trend from 2004 to 2007 until the government intervened by tightening loan-to-value ratios and raising mortgage interest rates throughout 2007. In the wake of the financial crisis, price-to-rent ratios fell but soon resumed their increase after the credit condition eased in late 2008 with measures to help first-time home buyers (see the appendix for details). Price-to-rent ratios then reached their historical highs particularly in the larger cities such as Beijing, Shenzhen and Shanghai ${ }^{4}$ (Fig. 2). Such price rises are not confined to luxury properties. Relative to rent, housing prices have been rising faster in the mass market than in the luxury counterpart. This is most readily observed in Shanghai ${ }^{5}$ (Fig. 3). Relative to the rental costs, an average residential unit in China is now more expensive than the same-sized units in comparator countries ${ }^{6}$ (Fig 4).

Meanwhile, real estate loan growth in 2009 has been high, both relative to past experience and regional comparators, increasing bank exposure to the property sector (Fig. 5). Mortgage loan grew by nearly 50 per cent, with year-on-year and mortgage loans risen from 10 to around 15 per cent of nominal GDP in 2008.

Despite rising house price trends, housing affordability has not worsened as much (Fig. 6), reflecting the rapid growth in the Mainland household disposable income and low costs of financing. Nevertheless, price-to-income ratios in selected big cities, which had been stagnant since mid-2009, are now starting to rise and housing affordability is beginning to worsen (Figs. 7 - 8). Current price-to-income ratios for China's cities are high compared to other regional cities $^{7}$ (Fig. 9).

3 The main differences between the two data sources are as follows: (a) the NDRC collects all transaction data available in 35 cities on all kinds of properties including residential and commercial buildings; (b) the NBS takes 10,000 samples in 70 cities of newly constructed and secondary properties; and (c) the NBS data are mainly provided by real estate developers who may not necessarily report the truth of property market development.

4 NDRC price and Centaline rent for mass market.

5 For the high-end segment, we use DTZ Property Research luxury house price and rent data during 2009-10 to get levels, and estimated levels backward using NBS city-level property price (new constructed) and rental price indices, respectively. The choice is made with consideration for maximum sample availability and consistency between price and rent series. For example, we avoid using NDRC price trend for Hangzhou because data are too fluctuating during 2004, and Centaline does not provide rent for Hangzhou and Nanjing while NDRC rent indices are too short.

6 Price to rent based on NBS reported series is used here, owing to more data availability. NDRC reported series date back only to 2004 and would give 30 per cent higher price-to-rent than NBS at the end of 2009.

7 For 70-square metre house price as a multiple of annual household disposable income. 
Fig. 1: Average house prices in major cities (Jan $2007=100)$

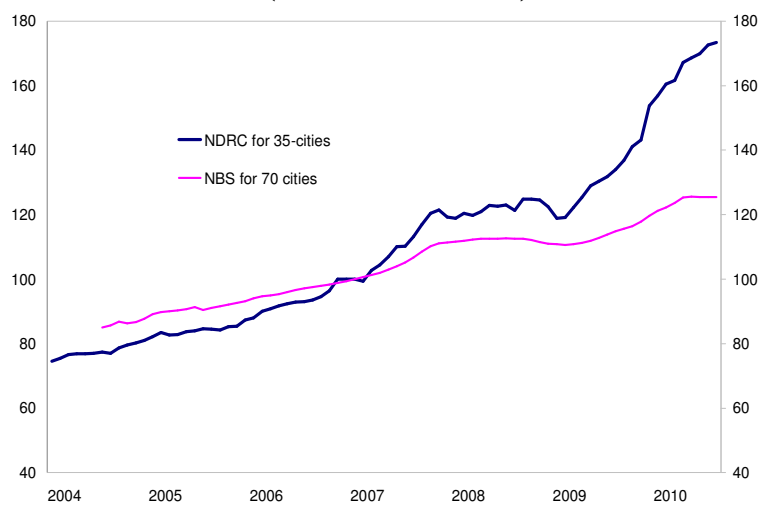

Fig. 3: House price-to-rent ratio in selected China's cities, high-end $(2004 \mathrm{Q3}=100)$

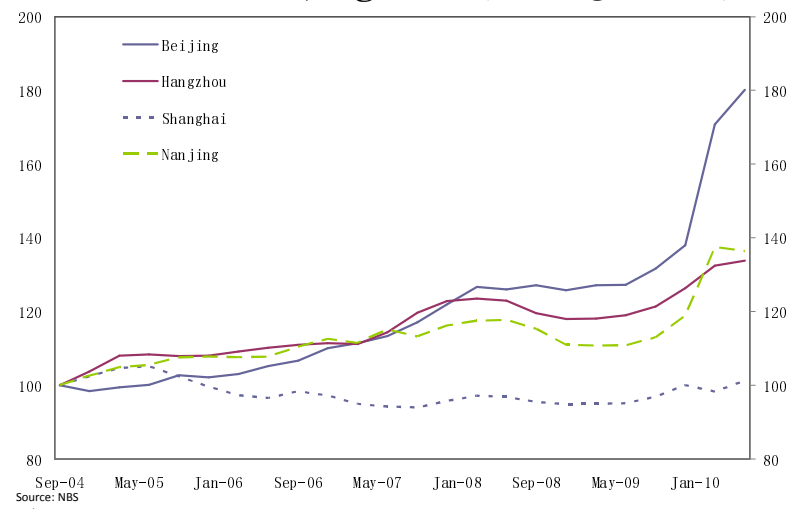

Fig. 5: Real estate loan growth, China and others (per cent, year on year)

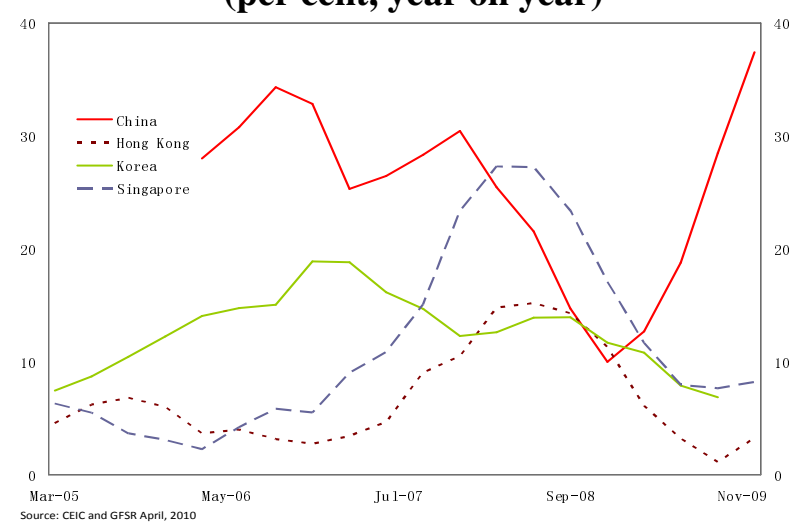

Fig. 2: House price-to-rent ratio in selected China's cities, mass market $(2004=100)$

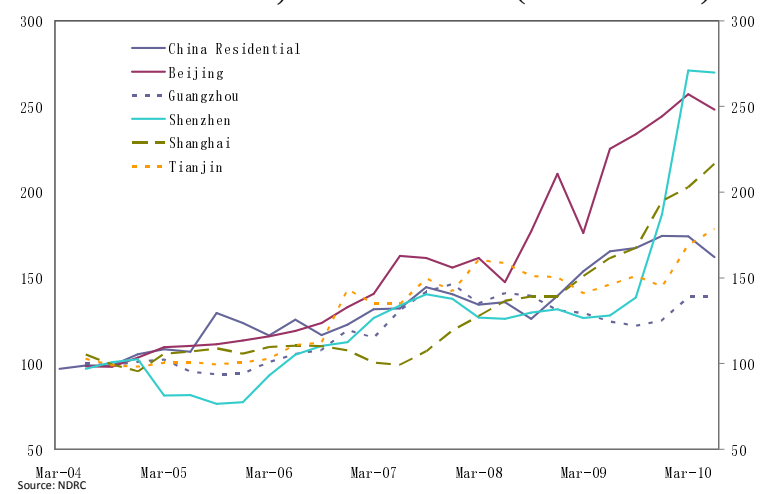

Fig. 4: House price-to-rent ratio, China and comparators $(2002 \mathrm{Q} 3=100)^{8}$

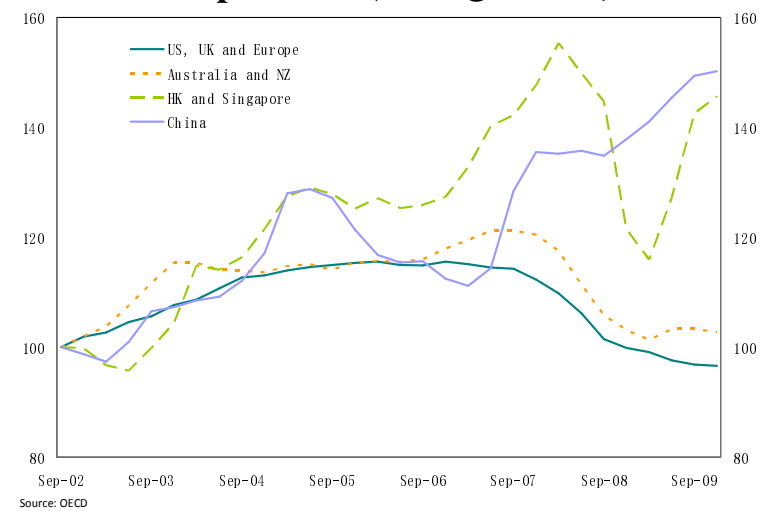

Fig. 6: House price to income, China and comparators $(2001=100)$

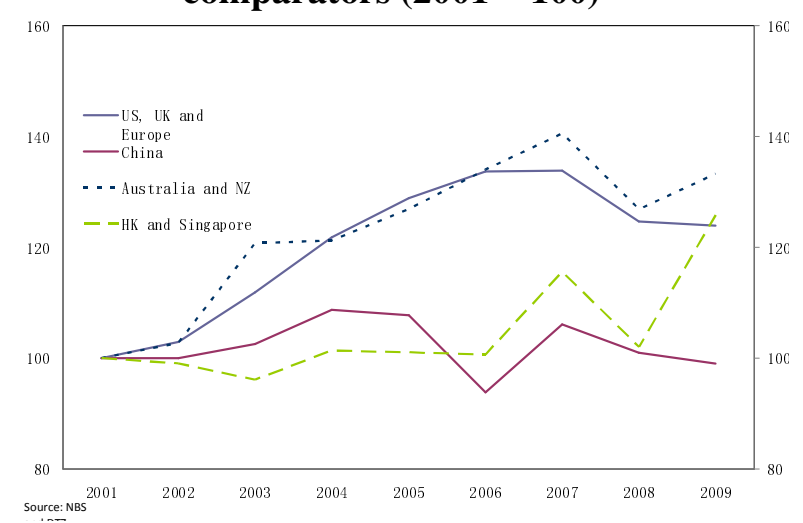

Sources: CEIC Data Company Ltd.; Centaline; DTZ Property Research; GFSR, April 2010; and authors' calculations.

8 Europe is represented by France and Spain. 
Fig. 7: House price to household disposable income in selected China's cities, mass market $(2004 Q 1=100)$

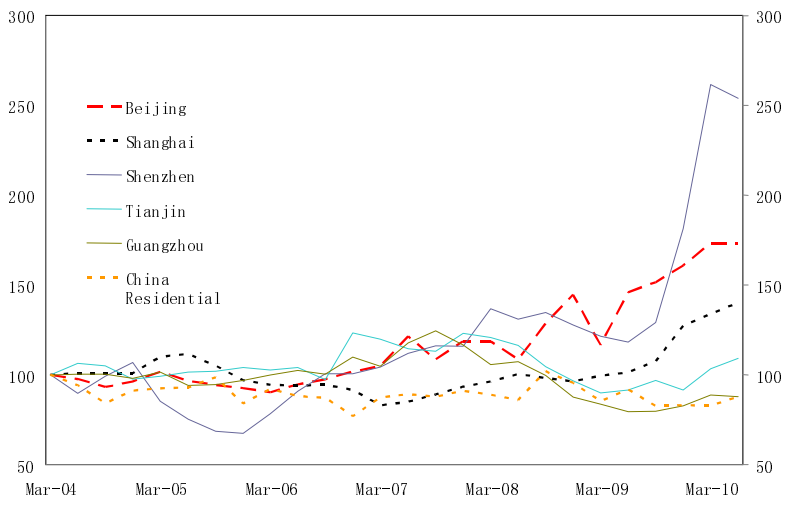

Fig. 8: Mortgage payment to household disposable income, mass market, China $(2004 \mathrm{Q} 2=100)$

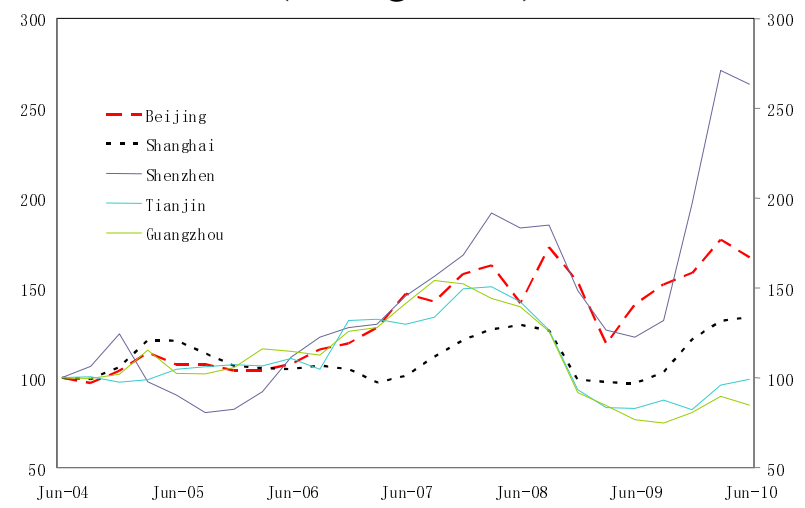

Fig. 9: House price to household disposable income across markets (levels)

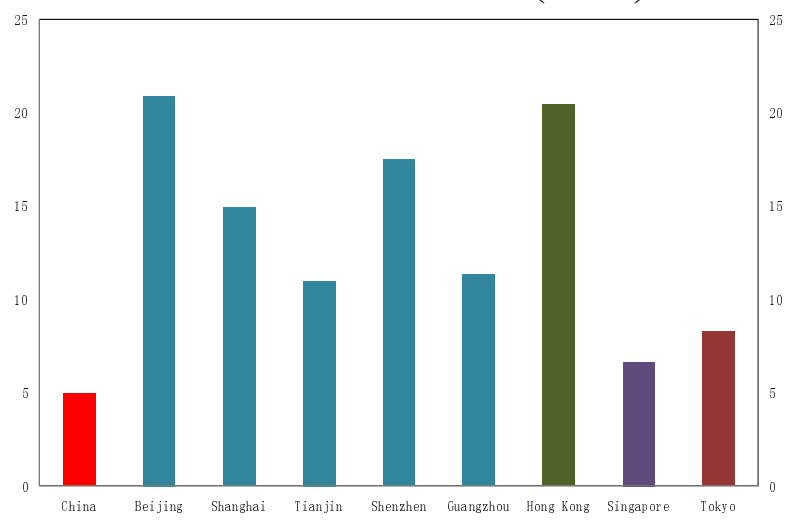

Sources: CEIC Data Company Ltd.; Centaline; NDRC; DTZ Property Research; GFSR, April 2010; OECD; and authors' calculations.

\section{How do We Assess Price Misalignment? Two Empirical Approaches}

Sharp price increases coupled with unprecedented lending growth have let many to question whether property prices are rising too fast in China that can be justified by fundamentals. As home ownership increases and house prices rise, household wealth and the impact they have on the macroeconomy and financial stability will depend more on the extent of price misalignment and the nature of their adjustment toward equilibrium. The larger the risk of a disorderly fall in house prices, the more vulnerable households and financial institutions become. Financial stability will depend on the size and persistence of price misalignment from medium-term fundamentals, which we focus on in this section.

Identifying a bubble is no easy task even in a mature market with decades of well-documented data. In China, the time series for house price and, especially, rents are short, and are not quality-adjusted. Moreover, private real estate markets are relatively new and rapid urbanisation makes market structure a non-constant factor that is difficult to deal with through econometric models. As a result, there is bound to be a large degree of uncertainty surrounding any estimated measure of equilibrium price. 
In light of data and market structure issues, we use two approaches to gauge how far market prices may have deviated from levels that reflect fundamentals that support prices in the medium term. We first estimate China's long-term equilibrium property prices using panel data at city level for 35 cities, following Glindro et al. (2008) and Leung et al. (2008). The results suggest that while property prices in some large cities appear to have been overvalued, nationwide risks of bubbles should not be overstated.

Complementing the regression exercise, we also undertake an analysis that compare actual property market prices with those suggested by asset pricing relationships. Beyond the national picture, we focus on markets with reported data on rent and price. In particular, we have been able to collect sufficient data on the the mass market segment in five cities-Beijing, Guangzhou, Shanghai, Shenzhen and Tianjin—as well as high-end markets in Beijing, Hangzhou, Nanjing and Shanghai. While the choice of these cities was necessitated by available rent data, they provide an important comparison with the national trend. In particular, these cities have better functioning rental markets than other Mainland cities and are amongst the wealthiest. They also have income much above the national average and have seen amongst the fastest growth in prices in recent times. Therefore, they are cities that are more likely to show sign of excessive price growth and speculation, raising concerns over the potential for a disorderly price adjustment. The results indicate that mass market residential property prices in Shanghai and Shenzhen, as well as high-end markets in Beijing and Nanjing appear to be overvalued during the first half of 2010, but those of other markets do not appear to be out of line with fundamentals.

\section{A. The panel regression approach}

We approach the problem through a dynamic OLS model that captures demand- and supply-side factors determining China's property prices. The determinants from the demand side include real lending interest rate, population density, and real GDP per capita, while the supply (cost) side is captured by land prices. Land prices can help capture an important driving force of China's property prices-that of local governments' fiscal financing through land sales. In addition, we include stock prices to capture the potential co-movement between equity and real estate prices. The model is specified as follows:

$$
\begin{aligned}
& P_{i, t}^{*}=c_{0}+c_{1} y_{i, t}^{*}+c_{2} r_{i, t}^{*}+c_{3} L_{i, t-2}^{*}+c_{4} D_{i, t}^{*}+c_{5} S_{t}^{*} \\
& P_{i, t}=P_{i, t}^{*}+c_{6} \sum_{j=-2}^{2} \Delta y_{i, t+j}+c_{7} \sum_{j=-2}^{2} \Delta r_{i, t+j}+c_{8} \sum_{j=-2}^{2} \Delta L_{i, t+j}+c_{9} \sum_{j=-2}^{2} \Delta D_{i, t+j}+c_{10} \sum_{j=-2}^{2} \Delta S_{t+j}+\varepsilon_{i t}
\end{aligned}
$$

where subscripts $i$ and $t$ represent city and time period, respectively. $P_{i, t}$ and $P_{i, t}^{*}$ 
denote the real actual and long-run property prices in log terms, while $y_{i, t}^{*}, r_{i, t}^{*}, L_{i, t}^{*}, D_{i, t}^{*}$, and $S_{t}^{*}$ denote the long-run values of real GDP per capita (in log), real lending interest rate (a proxy for real mortgage interest rate), land price index and population density of city $i$ at time t, and the long-run value of the Shanghai Composite Stock Exchange Index (in $\log$ ), respectively; $\Delta$ in equation (2) denotes the first difference, and $\varepsilon_{i t}$ the i.i.d. error term.

The long-run values of these explanatory variables are represented by the trend component of the time series, using HP filter. Equation (1) forms a co-integration relation for $P_{i, t}^{*}$. While $P_{i, t}^{*}$ captures the slow-moving, trend component of property prices, other terms in equation (2), namely the year-on-year growth rates of the explanatory variables, capture the cyclical story. ${ }^{9}$ We expect GDP, land prices, population density (which can partly capture migration into the cities) and stock prices to have positive impact on property prices, while an increase in real interest rates should lower property prices, ceteris paribus.

We estimate equation (2) after substituting away $P_{i, t}^{*}$ through equation (1), and then calculate $P_{i, t}^{*}$ according to equation (1). For simplicity, we impose two leads and two lags on the difference terms in equation (2). The estimation is undertaken for 35 cities using quarterly panel data of 2000Q1-2009Q4. A brief description of the data is presented in Table A2 in the appendix. The estimates of the $c_{i}$, where $i=0, . ., 5$ are given in Table 1. All estimated coefficients carry the right signs with significant t-statistics. ${ }^{10}$ A residual-based panel unit root test confirms that the regression residual is stable and, therefore, supporting the existence of the co-integration vector.

Table 1: Determinants of Long-Term Equilibrium Property Prices

\begin{tabular}{lcc}
\hline & Coefficient & t-statistic \\
Constant & 5.291 & 31.461 \\
Real interest rate & -0.020 & -2.616 \\
Real GDP per capita & 0.058 & 2.179 \\
Population density & 0.0002 & 6.888 \\
Land price & 0.001 & 9.541 \\
Stock price & 0.302 & 8.976 \\
\hline
\end{tabular}

9 In a slight departure from the traditional dynamic OLS model, the fundamental variables form a co-integration relationship in levels, while the relationship in "changes" represents a short-run deviation from trend.

10 We test for robustness by specifying a regression with construction costs and other factors that may influence demand for local real estate, (e.g. the numbers of hotels and schools), and find that they are statistically insignificant. 
The key results from the panel regression are:

- Factors that significantly explain long-term equilibrium house price trajectories in 35 cities in China include real income per capita, real mortgage interest rate, wealth levels (as represented by the market capitalisation of the Shanghai Composite stock exchange index), past land prices and degree of urbanisation/migration into the cities (as manifested through city-level population density).

- Overall property prices appear to have been in line with their long-term equilibrium values before 2006. However, property prices appear to be out of line with long-term fundamentals in some big cities. These include Beijing, Shanghai, Shenzhen, Ningbo, Fuzhou and Xiamen (all coastal cities), as well as Wuhan and Kunming (both are inland cities) (Fig. 10). Meanwhile, property prices in cities such as Nanjing, Hefei, Qingdao, Hohhot, Shenyang and Nanchang, which experienced notable drops during 2007 - 09, appear to have been somewhat undervalued with respect to their long-term fundamentals recently (Fig. 11).

\section{B. The asset pricing approach}

The purpose of this exercise is to gauge how far market prices may be deviating from benchmark levels that reflect the fundamentals, which would support prices in the medium term. Judgments on the level of prices are difficult to make, but it is possible to compare prices with those suggested by asset pricing relationships. The basis for assessing whether the level of house prices is "too high" or "too low" is as follows:In a housing market with well-functioning rental and credit markets, the cost of owning a house (in nominal terms), or imputed rent, should be the same as the cost of renting a similar house for the same time period. ${ }^{11}$ If ownership cost is higher than market rent for some time, then buyers may be overpaying for that property and should switch to renting a similar property instead. Such deviations would induce arbitrage through changes in rents as well as changes in investment plans, which ultimatly move the price towards its equilibrium.

In a frictionless equilibrium, a "no arbitrage" condition guarantees that the annual market rent is equal to annual cost of owning a property (or imputed rent):

$$
\begin{aligned}
& \boldsymbol{R}_{t}=P_{t}^{*} u_{t} \\
& u_{t}=r_{t}^{r f}+\omega_{t}-\tau_{t}\left(r_{t}^{m}+\omega_{t}\right)+\delta_{t}-E_{t} g_{t+1}+\rho_{t}
\end{aligned}
$$

11 See Poterba (1984) and Himmelberg et al. (2005). 
where $R_{t}, P_{t}^{*}, u_{t}, r_{t}^{n f}, \omega_{t}, \tau_{t}, r_{t}^{m}, \delta_{t}, E_{t} g_{t+1}$ and $\rho_{t}$ denote market rent, benchmark house price, annual total cost of ownership expressed in terms of cost per monetary unit of house value, risk-free long-term interest rate, the property tax rate, the income tax rate, mortgage interest rate, maintenance cost as a fraction of home value, expected annual capital gains, and an additional risk premium. Note that in an efficient-market equilibrium with no friction, $\boldsymbol{P}_{t}^{*}=\boldsymbol{R}_{t} / u_{t}$ should be equal to market price, $\boldsymbol{P}_{t^{3}}$ in every period.

Fig. 10: Potential property price overvaluation in Mainland's major cities

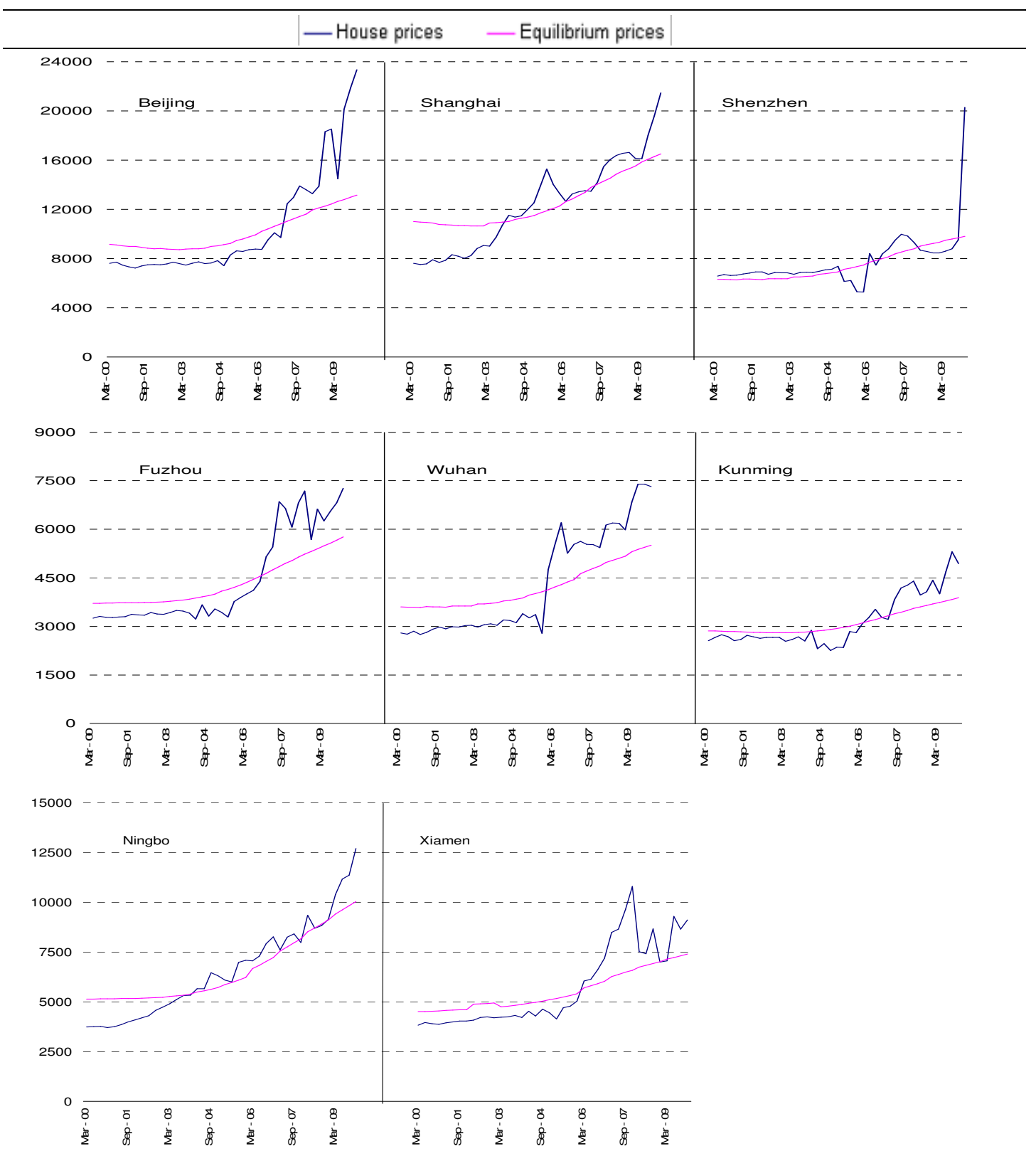

Source: Authors' estimates. 
Fig. 11: Property prices in other cities

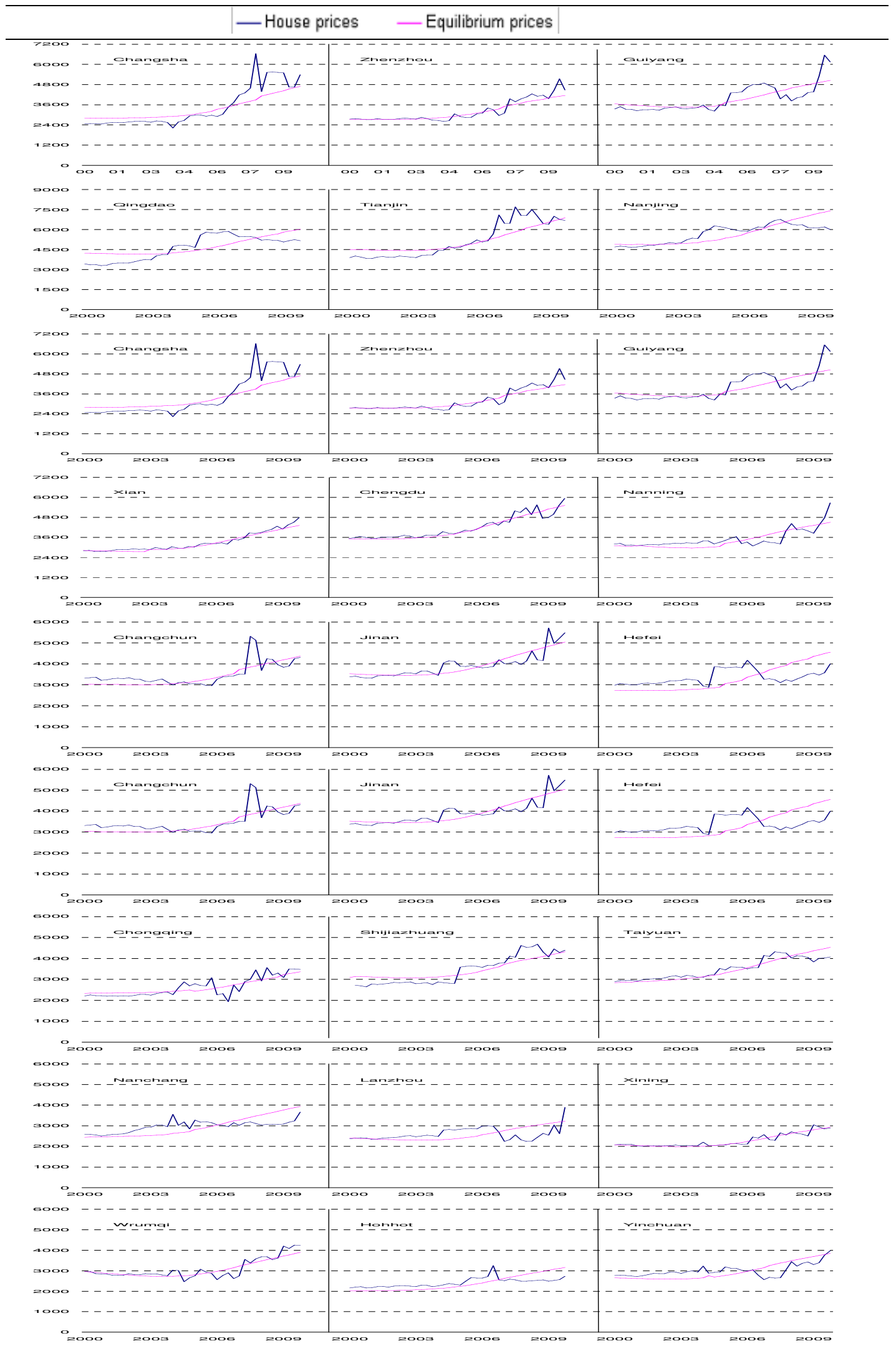

Source: Authors' estimates. 
Our strategy is simple: We calculate $P_{t}^{*}$ and compare it to market price. If there is a deviation between the two, $P_{v} / P_{\varepsilon}^{*} \neq 1$, then the market price should gradually move towards the benchmark. To calculate $P_{t}^{*}$, we use available information on market rent and fundamental determinants of user cost in equations (3) and (4).

Even when there are no other reasons for market inefficiency, the underlying assumption of low-cost arbitrage between owning and renting is unlikely to hold perfectly. In practice, with financial service fees and commissions as well as moving cost, swiching back and forth between renting and owning is not "costless." These transaction costs suggest that the deviation between market price and and benchmark price, $P_{t}^{*}=R_{t} / u_{t}$, can persist for some time before market forces work to close the gap. What we would label a misalignment is the type of deviation that is more persistent and sizable than can be reasonably accounted for by a normal transaction cost story.

Because the underlying metric is linked to market rent and a set of fundamental factors, this measure of price deviation should give us an early warning indicator of market exuberance that we can compare across cities and over time. ${ }^{12}$ However, it should be noted that while this measure can capture house price behaviour that may not be consistent with equilibrium, it is only a sufficient (and not necessary) condition for detecting a misalignment from slow-moving fundamentals in housing markets. Serious misalignment tends to become apparent after a substantial and typically abrupt price decline. For example, prices and rents could both move up together, making it appear as if actual prices are consistent with the benchmark prices. Despite this, both prices and rents could still face a sharp correction as the housing market deflates.

One important thing to note is that benchmark price should be higher in high average price growth cities, ceteris paribus, and changes in real interest rates or taxes would operate on a low ownership cost base, yielding a larger percentage effect on rent-to-price ratio. In typically high growth cities, therefore, the effect of changes in fundamentals on benchmark prices (relative to rents) would be larger.

12 We should be cautious when comparing prices or rents across cities, particularly because they are not controlled for quality changes. The fundamental-implied price is calculated from rent-to-user cost ratio of a housing unit in a given locality where rental market is well functioned and quality of a rental unit should change at a similar rate as that of an owned unit. 
How we calculate $P_{t}^{*}$

For risk-free interest rate, we use 5-year treasury bond yield (or equivalent). For mortgage interest rate, we use nominal lending rate on housing loan (at least 5 years). For maintenance cost, we assume a constant annual depreciation rate of 2.5 per cent (following Harding, Rosenthal and Sirmans, 2007). For countries or localities that have arrangements for tax deductibility for mortgage and property tax payments, we use the marginal tax rate of the typical homebuyer (the tax rate that applies at per-capita household income level). For rent, we use market rent data in national currency per square metre from the same market segment as that for which we wish to calculate benchmark price. All house prices and rents are seasonally adjusted. ${ }^{13}$

We assume that (1). buyers form their capital gains expectation according to past observation as well as their local knowledge about future price dynamic; and (2). the relative risk of owning versus renting can vary slowly over time. In practice, these two variables are difficult to observe or measure. We use average trend growth rates (a constant) to represent "normal" expected future house price growth for each market. ${ }^{14}$ The risk premium should, among others, depend on the degrees of price and rent fluctuation and the ability of homeowners and renters to hedge risks, which may not be constant over time and may fluctuate more in a crisis. We rely on equations (3) and (4), assuming market price is equal to benchmark price on average, to extract the risk premium from the data and use its slow-moving component to represent the risk premium in our calculation of the user cost. ${ }^{15}$

In our framework, fluctuations in the benchmark price are associated with changes in market rent and long-term changes in real interest rates, taxes, maintenance costs, "normal" expectation of capital gains and "normal" premium. They reflect changes in fundamental factors. In fact, as these fundamental factors change smoothly over time, most of the fluctuation in our benchmark price reflect changes in market rent. After these fundamental factors are accounted for, the remaining fluctuations in price are associated with "excessive" fluctuations in house price expectation or in the premium.

13 See Table A3 for the details of data used in this analysis.

14 Other studies cited earlier tend to proxy expected house price growth with some constant average historical rates. With less than a decade's worth of data on house prices and the rapid change China's markets are undergoing, we cannot avoid using current data to gauge the "normal" size of capital gains expectation.

15 We learn from talks with market specialists that the majority of Mainlanders overwhelmingly prefer owning to renting. This should translate into lower risk premium in China than elsewhere. Data show this to be the case as well. 


\section{International comparators}

This methodology gives results that capture large and persistent pre-crisis deviation from benchmark prices in known cases of "full blown housing bubbles," such as those in the United States, New Zealand and France.

Given the assumptions outlined above, the gap between house prices and their benchmarks show sizable and persistent overvaluation in the housing markets in the U.S., France, and New Zealand (Table 2). With small sample, the ADF test has no power to reject the null hypothesis of a unit root in the price deviation data in these cases. If we model these deviations as following an AR(1) stationary process, their estimated AR coefficients would be close to 1, which means a highly persistent half life. A build-up in housing price misalignment can require years to become apparent. Serious misalignment tends to become apparent after a substantial and typically abrupt price decline. Nevertheless, a substantial degree of price correction seemed to have taken place along the way in Australia and the UK (Fig. 12).

Table 2: Deviation between price growth and benchmark price growth (2002 Q4-peak)

\begin{tabular}{lccccc}
\hline & $\begin{array}{c}\text { Annual } \\
\text { average price } \\
\text { growth ( per } \\
\text { cent) }\end{array}$ & $\begin{array}{c}\text { Annual average } \\
\text { benchmark price } \\
\text { growth } \\
\text { ( per cent) }\end{array}$ & $\begin{array}{c}\text { Difference } \\
\text { (per cent per } \\
\text { annum) }\end{array}$ & $\begin{array}{c}\text { Deviation at } \\
\text { peak } \\
\text { (per cent of } \\
\text { benchmark } \\
\text { price) }\end{array}$ & Quarter at peak \\
\hline US & 5.9 & 3.2 & & 8.7 & 2006 Q4 \\
France & 9.6 & 4.5 & 2.6 & 24.3 & 2008 Q1 \\
New Zealand & 11.3 & 6.4 & 4.9 & 25.2 & 2007 Q4 \\
UK & 6.6 & 6.0 & 0.6 & 7.1 & 2008 Q1 \\
Australia & 5.3 & 4.0 & 1.3 & 10.0 & 2008 Q2 \\
\hline
\end{tabular}

Fig. 12: Market price and benchmark price indices $(2002 \mathrm{Q} 4=100)$

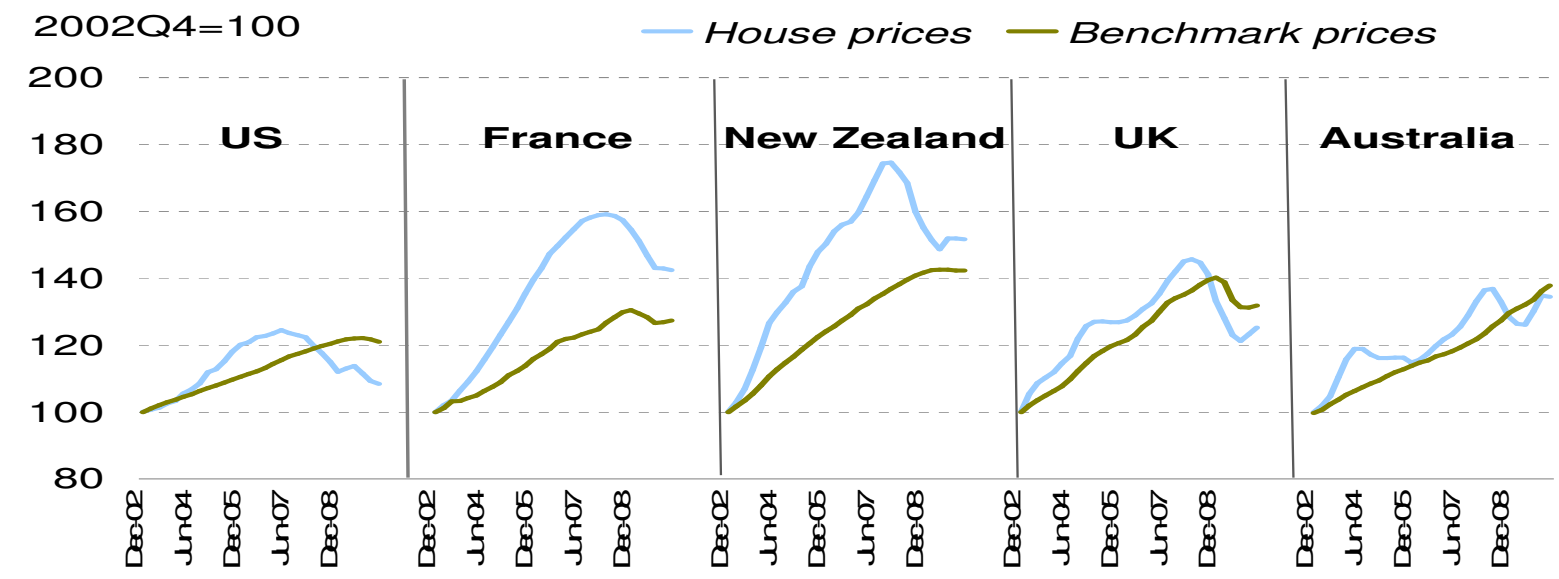

Sources: CEIC Data Company Ltd., NDRC, NBS, DTZ Property Research, OECD, and authors' calculations. 
Are there signs of house price misalignment in China today?

To capture price and rent dynamic in the mass market, we use NDRC price data and Centaline data for rents for the mass market segment. High-end prices are obtained from DTZ Property during 2009 - 10 and estimated backward based on NBS city-level price indices. High-end rents are also obtained from DTZ Property during 2009-10 and estimated backward based on NBS city-level rent indices. The choice is made with consideration for maximum sample availability and consistency between price and rent series.

The main findings are as follows:

- Despite sharp rises in price-to-rent across China's residential real estate markets, we find limited deviations from our benchmark measure in the overall real estate market and the overall residential market in China in $2010 \mathrm{H} 1$. Overall prices are roughly aligned with benchmarks, and prices have risen alongside rents and falling user costs (e.g., real interest rates) (Figs. 13a-13d).

- However, mass-market house prices in Shanghai and Shenzhen, as well as luxury house prices in Beijing and Nanjing, were more than 10 per cent away from benchmark levels in $2010 \mathrm{H} 1$, an indication that they may be in the early stages of excessive price growth (Fig. 14). Recent policy measures to cool down the markets unveiled by the Government in April 2010 was therefore timely.

- In the second quarter of 2010, price growth has slowed down and the gap between price level and benchmarks has narrowed in some cities. Recent policy efforts therefore appear to have already had some impact.

A few key observations emerge from this exercise:

- First, since 2004, the deviation of overall real estate and overall residential market prices from their respective benchmark levels has not been persistent. Markets and policy measures seem to be able to work to close those gaps in a relatively short period of time. House price deviation tend to be corrected relatively quickly, with an estimated half life of around one quarter for China as a whole (an estimated AR coefficient of 0.32). Deviation from benchmark also tends to halve in a few large Mainland cities such as Beijing and Tianjin quickly at around one to two quarters, whereas the same process could take from roughly 4 quarters in Shenzhen and Guangzhou to seven quarters in Shanghai. This observation suggests that there has not been significant price misalignment in the overall Mainland real estate and residential market. The same cannot be said, however, for mass market prices in 
Guangzhou, Shenzhen and, to some extent, Tianjin. In these cities, the deviation from benchmark prices appeared to have been narrowed only by the policy steps taken in 2007.

- Secondly, the series of policy measures taken to tighten credit availability in 2007 appear to have been associated with a fall in housing prices in many markets, except most notably in Beijing and Shanghai which only see a slowdown in price growth. ${ }^{16}$ These policies appear to have helped restore price levels toward benchmarks in Guangzhou, Shenzhen and Hangzhou, but not so much in Tianjin (where prices did not start to fall until 2008 Q4). Meanwhile, the market price seems to have undershot its fundamentally-implied benchmark in Nanjing and may have done so in overall China in 2008.

We do not detect a fall in the benchmark price in the data during or a year after 2007 Q3 when the authorities implemented a measure that increased both nominal lending and collateral rates. ${ }^{17}$ The lending rate did not appear to rise by enough to effect an increase in the real long-term lending rate in the periods following 2007 Q3. In all cases, benchmark price-to-rent kept increasing even after the policy rate was increased.

While we do not have data on loan-to-value ratios for mortgage loans originated in China to compare with house prices, the timing of measures to vary loan-to-value for home buyers in the first quarter of 2010 appears to have dampened house price inflation. However, prudential measures alone, without a change in the cost of capital, may remove leverage from the market for a time, but do not seem to change the underlying pressure on prices. Low cost of capital (by equations (3) and (4)) imply a high price-to-rent ratio. Eventually, market prices would rise to reflect this relationship despite the prudential or quantitative measures on credit, as the incentive to overcome prudential control or for external funds to enter the market increases. This is seen, to differing extents, in the behaviour of market and benchmark prices following the 2006 - 07 tightening measures. While these measures temporarily lowered prices or reduced property price inflation, they did not slow down the growth in benchmark prices, and market prices eventually began to rise again.

16 Among measures implemented is an increase in the lending rate from 0.85 to 1.1 times the benchmark lending rate and an increase in the down payment (or collateral rate) for second homes from 30 to 40 per cent in 2007 Q3. These policy measures, in effect, dampen the leverage cycle. (We would be able to identify the effectiveness of changes in the down-payment or leverage ratios better if actual data were available.)

17 The dampening of the leverage cycle (which is the reciprocal of the mortgage loan-to-value ratio) should lower buyers' expectation of price growth or, as a signal of increasing disagreement about the future, raise the premium home buyers demand. Both effects should raise the benchmark user cost and bring down equilibrium price-to-rent. This is what we see in the benchmark prices if we relied solely on NBS house price data to construct them. NBS price and rent data would yield a rise in the calculated user cost mostly from premium increase. 
- Thirdly, going forward, an increase in the real interest rate from the current low base (indeed in negative territory) would have a larger effect on the price-to-rent multiple in lower user cost (higher benchmark price-to-rent) areas like Beijing, Guangzhou, and Shenzhen. Indeed, the lower the user cost, the higher the sensitivity of the rent multiple to changes in interest rates. For example, with user cost registering at roughly two per cent in Beijing mass market housing segment, an increase of one per cent in real interest rate increase would work on that low user cost base and translate into an eventual drop in benchmark price-to-rent ratio of about 33 per cent (Table 3 ). With a three per cent user costs in Guangzhou and Shenzhen, the price-to-rent multiple would decline from 33.3 to 25 (a fall of 25 per cent). The impact on the price-to-rent multiple of a one percentage point rise in property tax is equal to that of a fall of one percentage point in house price growth expectation or a 100-basis-point increase in real interest rate in China, where mortgage payment tax deductibility is not allowed.

As to whether rents would adjust upward or price would have to fall to achieve these new multiples, we cannot say with certainty within this framework. If the past is any indicator, prices have been much more volatile than rents (Table 4), especially in Beijing, Shenzhen and Shanghai. This would suggest that the required adjustment in price-to-rent multiples would likely come more from a fall in prices than a rise in rents.

Fig. 13a: Market prices and benchmark prices, mass market, China (1)

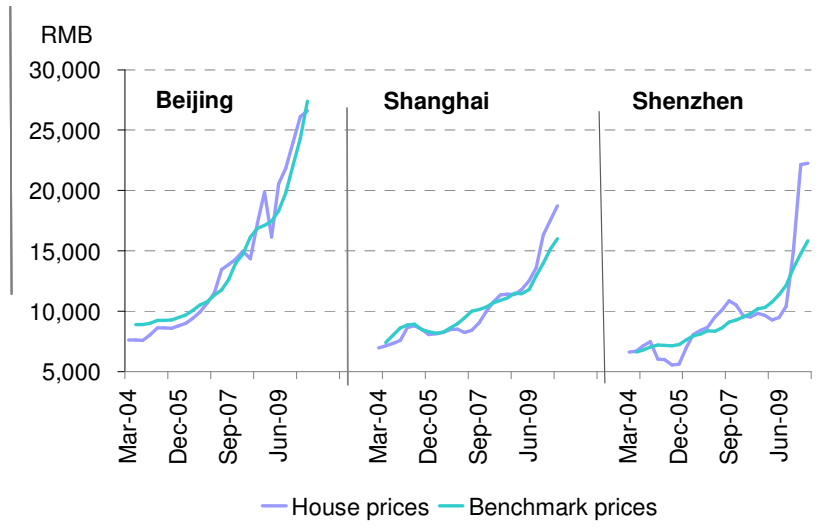

Fig. 13c: Market prices and benchmark prices, high-end, China (1)

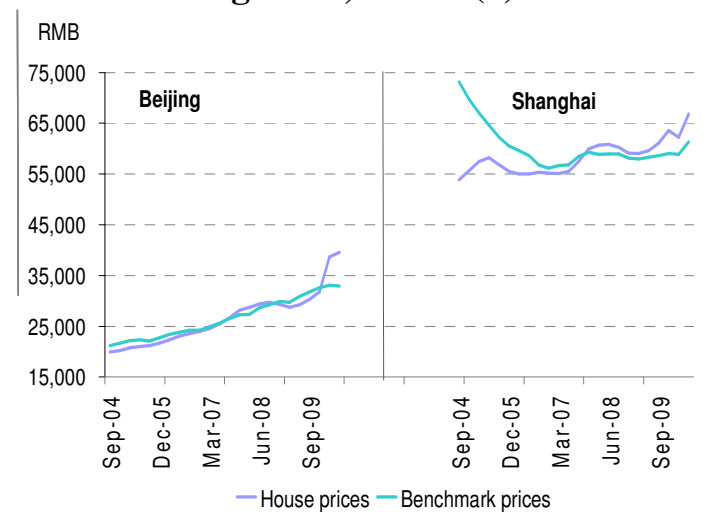

Fig. 13b: Market prices and benchmark prices, mass market, China (2)

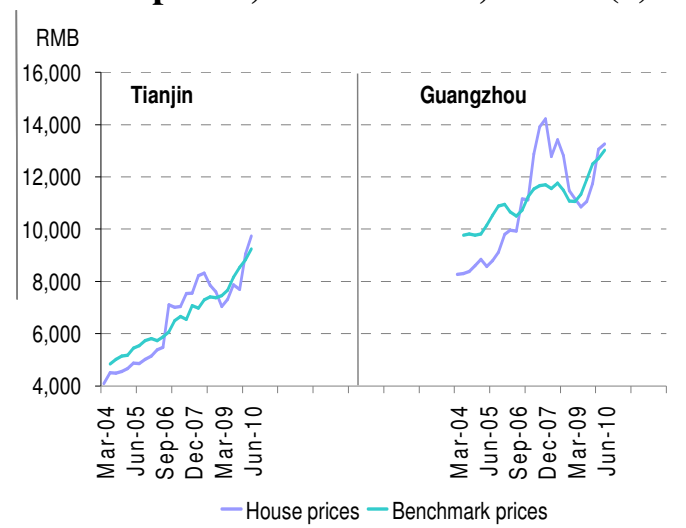

Fig. 13d: Market prices and benchmark prices, high-end, China (2)

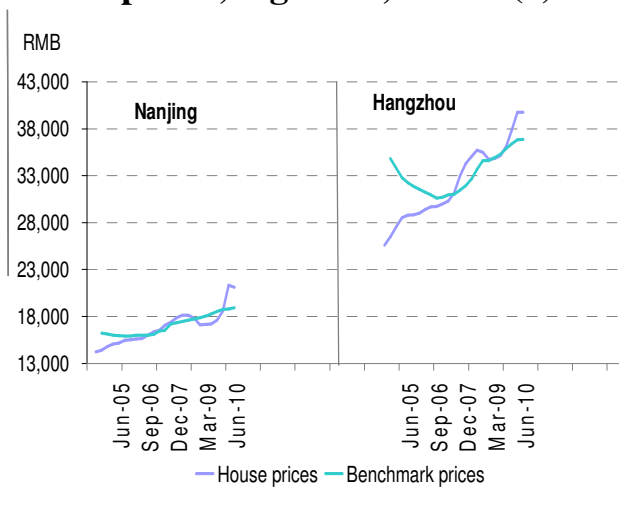

Sources: CEIC Data Company Ltd., NDRC, NBS, DTZ Property Research, OECD, and authors' calculations. 
Fig. 14: Deviation of house prices from benchmark, China (as a percentage of benchmark prices)

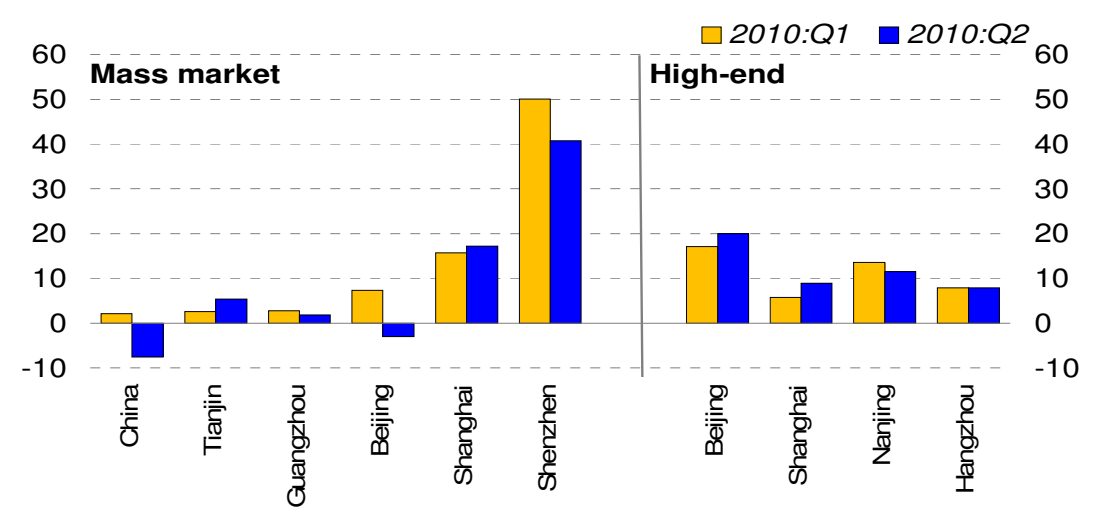

Source: Authors' estimates.

Table 3: Impact of a one per cent increase in user cost on price-to-rent multiples in selected Mainland cities

\begin{tabular}{lcc}
\hline & $\begin{array}{c}\text { Current User Cost } \\
\text { ( per cent, approx.) }\end{array}$ & $\begin{array}{c}\text { Decline in P/R multiples } \\
\text { ( per cent, approx.) }\end{array}$ \\
Beijing & 2.0 & 33.0 \\
Hangzhou/Guangzhou/Shenzhen & 3.0 & 25.0 \\
Shanghai/Tianjin & 3.6 & 21.0 \\
Nanjing & 7.0 & 11.0 \\
\hline
\end{tabular}

Table 4: Coefficients of variation of rents and prices in selected Mainland cities

\begin{tabular}{lcc}
\hline & C.V. (Rent) & C.V. (Price) \\
\hline Beijing & 0.11 & 0.44 \\
Guangzhou & 0.05 & 0.18 \\
Hangzhou & 0.05 & 0.13 \\
Nanjing & 0.03 & 0.11 \\
Shanghai & 0.06 & 0.31 \\
Shenzhen & 0.04 & 0.44 \\
Tianjin & 0.05 & 0.25 \\
\hline
\end{tabular}

Underlying the price build-up is expansionary credit condition. Even from high bases, mortgage-to-nominal GDP growth rates in comparator countries far outstrip that in China between 2004 - 07 (Table 5). After 2007, mortgage loan growth (relative to nominal GDP) falls by half in UK and New Zealand after 2007. China's mortgage market is relatively new and has expanded at a relatively modest rate until 2009 when the level of mortgage loan to nominal GDP surges. If continued, mortgage loan growth of this magnitude can create more house price inflation and pose risk to financial stability down the road. 
Table 5: Mortgage market depth and growth

\begin{tabular}{|c|c|c|c|c|}
\hline & \multicolumn{2}{|c|}{$2004-2007$} & \multicolumn{2}{|c|}{$2008-2009$} \\
\hline & $\begin{array}{l}\text { Mortgage/Nominal } \\
\text { GDP ( per cent) }\end{array}$ & $\begin{array}{l}\text { Average growth } \\
\text { rate ( per cent) }\end{array}$ & $\begin{array}{l}\text { Mortgage/Nominal } \\
\text { GDP ( per cent) }\end{array}$ & $\begin{array}{l}\text { Average growth } \\
\text { rate ( per cent) }\end{array}$ \\
\hline US & 76.1 & 4.2 & 76.3 & \\
\hline UK & 80.4 & 5.5 & 89.4 & 2.5 \\
\hline France/Spain & 42.6 & 11.5 & 51.8 & 4.5 \\
\hline Australia & 82.3 & 5.0 & 91.8 & 4.3 \\
\hline New Zealand & 81.7 & 8.7 & 96.7 & 4.4 \\
\hline China & 10.4 & 2.4 & 11.8 & 16.1 \\
\hline
\end{tabular}

\section{Impact on China's Real Economy and BANKIng SECTOR From Property Price Changes}

Given the importance of the real estate sector in China's economy, the adverse impact of abrupt corrections in property prices is a serious concern. Against this backdrop, this section studies to what extent property price changes may affect China's real economy and banking sector.

Our analysis shows that while property price movements may not generate significant impacts on China's private consumption, the effects on investment can be sizable. Meanwhile, the banking sector's direct exposure to the real estate sector seems limited and manageable, but the total exposure is sizable owing to the strong linkages between real estate sector and other industries, as well as to the loans using properties as a collateral. As land sales account for a large share of local governments' revenues, sharp drops in property price may also generate some negative impact on government revenues from land sale, as the chance of failure of land auctions under such a circumstance could rise rapidly.

\section{A. How will property price changes affect China's domestic demand?}

Generally speaking, property price adjustments can affect private consumption through three major channels. First of all, they affect house owners' lifetime wealth. This channel does not appear to be important in China, as income from properties including rental income and returns from property transactions accounts for only about two per cent of China's total per capita income in urban areas (Fig. 15). Secondly, property price changes can affect household expectations of future income growth through changing investment and output. Finally, changes in property prices may affect household financing constraints. Following Peng and Cheung (2001), we estimate the impact of property price changes on consumption and investment through the following relationships:

$$
\Delta C_{i, t}=\alpha_{0}+\alpha_{1} \Delta Y_{i, t-1}+\alpha_{2} \Delta P_{i, t}+\alpha_{3} r d_{t}
$$




$$
\Delta I_{i, t}=\beta_{0}+\beta_{1} \Delta Y_{i, t-1}+\beta_{2} \Delta P_{i, t}+\beta_{3} U C_{i, t}
$$

where $\Delta C_{i, t}, \Delta I_{i, t}, \Delta Y_{i, t}, \quad r d_{t}, \Delta P_{i, t}, U C_{i, t}$ denote real private consumption growth (of province $i$ ), growth of real gross capital formation, real GDP growth, one-year real deposit rate, property price inflation, and user cost of capital constructed according to Romer (2001), respectively:

$$
U C=\frac{P_{I}}{P_{Y}} \frac{R R+D E P-\left(\Delta P_{I}-\Delta P_{Y}\right)}{1-\tau}
$$

where $R R, D E P, P_{I}, P_{Y}$ and $\tau$ are one-year real interest rate, the depreciation rate of capital stock (set here at 2.5 per cent), investment deflator, GDP deflator, and the tax rate (national tax revenue over national GDP). We estimate equations (5) and (6) with annual panel data at provincial levels for 1994-2008, with results displayed in Table 6.

Our analysis based on panel data at provincial level of $1994-2008$ shows the overall impact of property price changes on China's private consumption would be insignificant, with a 10 per cent drop in property prices likely to induce a fall in private consumption by 0.7 per cent.

In contrast, the potential impact of property price changes on investment could be much larger. Our estimates show that a 10 per cent drop in property prices can decrease China's investment by about 4 per cent. Indeed, real estate fixed-asset investment (FAI) accounts for a notable part of China's total FAI in the past few years (Fig. 16). The importance of real estate investment differs notably across regions. While real estate FAI accounts for around 50 per cent of Beijing's total FAI in the past couple of years, it has been less than 30 per cent of Guangdong's total FAI. Meanwhile, property price movements can also affect aggregate investment indirectly through reducing the demand for investment of those factors closely linked with property markets including building materials and transportation. 
Table 6: Estimates of parameters in equations (5) and (6)

\begin{tabular}{lrr}
\hline & Estimate & T -statistic \\
\hline$\alpha_{1}$ & 0.519 & 3.66 \\
$\alpha_{2}$ & 0.07 & 1.318 \\
$\alpha_{3}$ & -0.304 & -2.451 \\
$R^{2}$ & & 0.207 \\
\hline$\beta_{1}$ & 1.371 & 8.585 \\
$\beta_{2}$ & 0.441 & 5.045 \\
$\beta_{3}$ & -0.64 & -5.171 \\
$R^{2}$ & & 0.47 \\
\hline
\end{tabular}

Fig. 15: Share of property income in total per capita income in China's urban areas

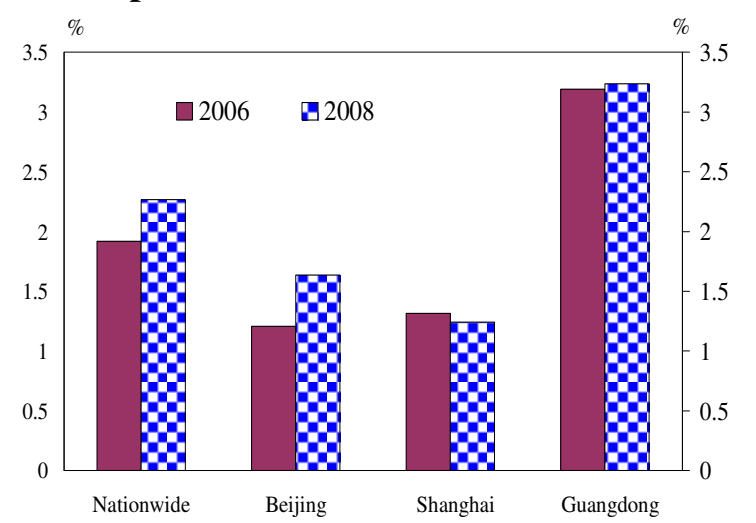

Sources: CEIC; China Urban Life and Price Yearbook 2007; and authors' estimates.
Fig. 16: Share of real estate FAI in total FAI

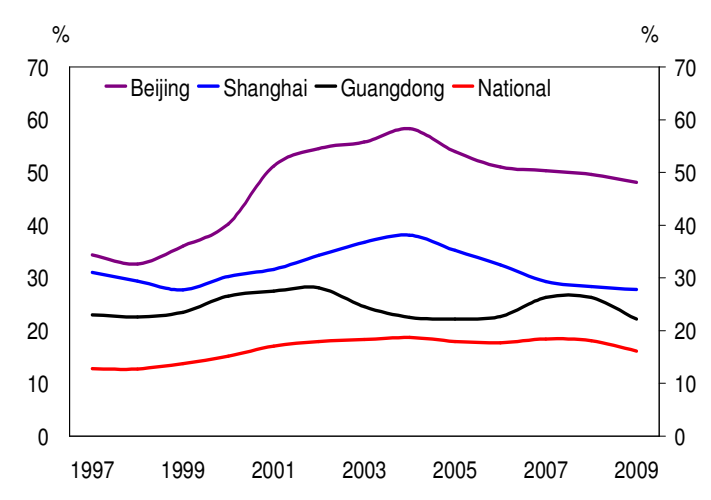

Sources: CEIC; and authors' estimates.

\section{B. How will property price changes affect China's banking sector?}

Banking sector's direct exposure to property markets looks manageable. Mortgage loans and the loans to developers have been trending up in the past few years, but still account for less than 20 per cent of total outstanding loans in late 2009, compared with 51.6 per cent in the Hong Kong SAR and 56.6 per cent in the US (Fig. 17). On the other hand, loans from financial institutions are not a major source of funding for developers. Self-raised capital, advanced payment, and other sources of funding in 40 major cities, for instance, account for about 60 per cent of developers' total funding in the first quarter of 2010.

Nevertheless, banking sector's total exposure to property markets can be large because of the strong linkages between real estate sector and other industries. The cumulative input coefficients of the construction sector can in large part capture how real estate sector is linked with other industries. They illustrate how much output from other sectors is used as intermediate inputs to produce an additional unit of construction on a gross basis (Fig. 18). The metal smelting and rolling sector appears to be most closely linked with the construction sector, followed by non-metal mineral products and chemical 
sectors. A one-yuan of final demand for construction, for example, will require an input of 0.40 yuan from the metal smelting and rolling sector. In fact, the amount of loans to the sectors that are closely linked with the property market is large, accounting for about 24.0 per cent of total loans in 2009 (Fig.19). Falling property prices will affect these sectors' output and hence erode their ability to repay loans to banks.

The above analysis captures better the banking sector's exposure to the property market, but may still underestimate its exposure as firms may use their properties as collateral to borrow money from banks. Property price corrections will reduce the collateral values and hence hurt banks' balance sheets if borrowers default on loans. While no official data on these collateralised lending activities is available, anecdotal evidence suggests banking sector's indirect exposure to property markets through this channel is significant.

Fig. 17: Banking sectors' direct exposure to property market

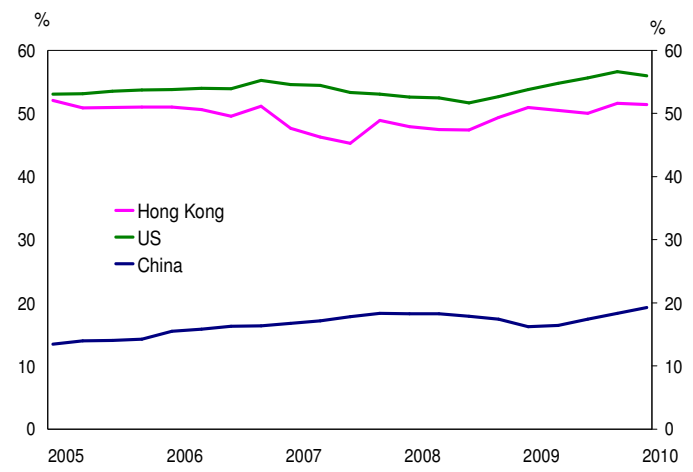

Sources: CEIC; US Federal Reserve; and authors' estimates.
Fig. 18: Cumulative input coefficients of the construction sector

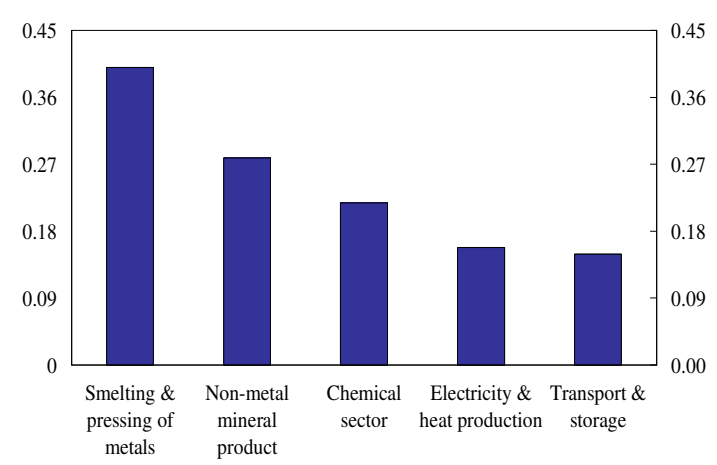

Sources: 2007 China Input-Output Table; and authors' estimates.

Fig 19: Distribution of outstanding loans in 2009

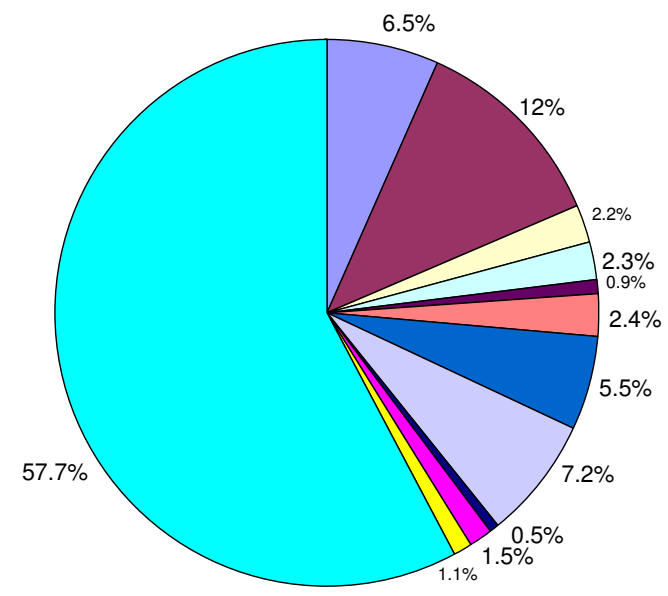

Note: Figures do not add up to $100 \%$ because of rounding. Sources: CEIC; and authors' estimates.

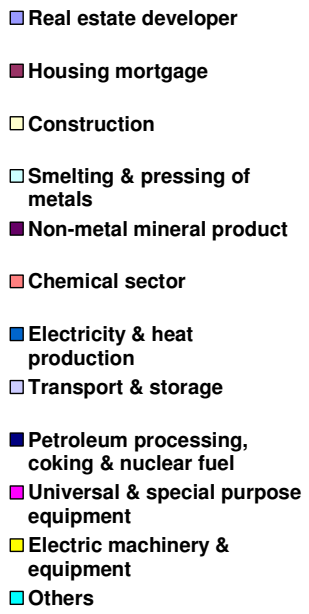

$\square$ Others 


\section{How will property price changes affect government revenue?}

Property prices can affect government revenue mainly through government general revenue, which mainly consists of various types of taxes, and land sales revenue, which depends on land prices and has become an important source of the extra-budgetary revenue to China's local governments. The share of land sales revenue to local government revenue at provincial level differs significantly across regions. For example, Chongqing's land sales revenue is more than 30 per cent of government general revenue while Shanghai's has been below 10 per cent in the past few years (Fig. 20).

Fig. 20: Land sales as a percentage of local government general revenue

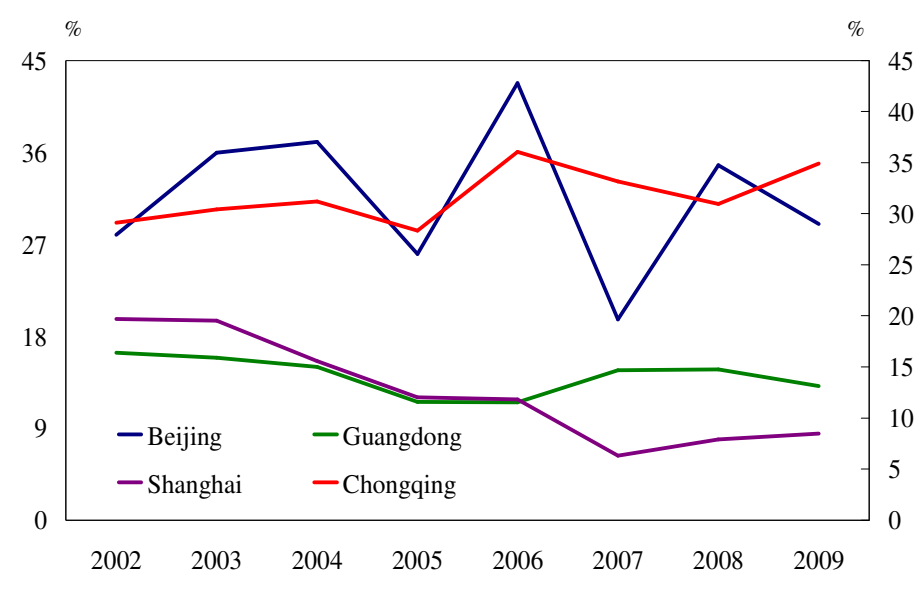

Sources: CEIC; and authors' estimates.

\section{What are the Policy Implications?}

While there is no sign of broad-based and significant over-valuation of residential property prices in China today, there is a risk that property values in large cities are deviating from fundamentals.

China's experience has shown that leaning against the wind with regulatory measures may not be enough to address what is fundamentally a structural problem. Credit controls seem to work well for a time, temporarily lowering prices, affecting expectations, and reducing property price inflation. However, such measures do not directly affect the benchmark prices, and so the tendency is there for market prices to eventually rise again.

Within the analytical framework we put forth, the deeper cause of a higher propensity for sharp house price inflation in China and the associated risk of price misalignment and financial instability remains largely intact. At its root, high demand for real estate in China is propped up by low perceived cost of home ownership. 
Structurally low real interest rates (particularly relative to income growth), high savings (and therefore ample liquidity), and a lack of alternative investment and property tax all work to promote excessive house price inflation. ${ }^{18}$

First, real long-term interest rates have been negative for the past five quarters (calculated at 2 per cent medium-term inflation) in China. Considering that real output growth has far outstripped comparator economies over the past decade and productivity is extremely high, real long-term interest rates should be higher. If house prices had reflected the natural levels of interest rates, home buyers would have found it more costly to own.

Secondly, variation in leverage can have large impact on asset prices. ${ }^{19}$ As we have witnessed in the recent global financial crisis, leverage can become too high in boom times and too low in bad times. While information on actual housing loan-to-value ratios in China is unavailable, the fact that the authorities have been active in managing system-wide leverage - curbing leverage during boom time and propping it up when market may be anxious - suggests that they do monitor changes in the leverage cycle.

Thirdly, on top of low real interest rates and independent of leverage, China's households are more likely than others to be natural buyers of real estate. They are more likely to be optimistic from past experience of robust growth, have no other investment alternatives either locally or overseas for high savings and prefer collateralisable assets without significant tax consequence on their value. Residential real estate is a natural investment choice in China. In addition, there is no powerful tool with which the pessimists can express a different point of view regarding future asset price trajectories (for example, by shorting the market).

As property prices rise beyond fundamentals, an abrupt shift to home buyers' degree of optimism, rising ownership cost and disruption to buyers' ability to borrow could cause a significant correction in prices. Internationally, it is typically the case that real interest rates rise just before a housing bust (IMF, 2003).

When prices fall, there is a risk that they then undershoot their fundamentals for a time damaging the balance sheets of households, firms, financial intermediaries and disrupting economic activity (notably real estate investment). At present, given the awareness of the risks, policymakers' actions to lean against house

${ }^{18}$ From 2001 to present, real interest rate on 5-year Chinese government bond has averaged at 0.8 per cent, while comparable real interest rates in other economies range from 1.4 per cent in the euro area to 3.9 per cent in New Zealand. Even these figures are considered by some to be too low to contain a significant asset price buildup shown in the previous sections, and indeed may have amplified the asset price cycle.

19 Geanakoplos (2010a) and Shin (2009) discuss the role of leverage cycle in cases of asset price boom-bust cycle. Fostel and Geneakoplos (2008) analyses the role of leverage in a credit constrained "anxious" economy with heterogeneous agents. 
price inflation through credit curtailment, and the tools at the government's disposal should there be a large housing price correction, the risk of a sharp and broad-based decline in real estate prices is low. However, to tackle the structural drivers of rising house price, the government would need to take steps to raise real interest rates, impose a meaningful property tax and ensure that leverage does not accelerate. Moving in this direction carries some risk of itself precipitating an asset price adjustment, but if well calibrated, such steps should reduce the risk of a disorderly fall in prices.

\section{CONCLUSION}

We have compared movements in China residential property prices with those implied by market fundamentals. Our approaches to measuring the equilibrium price are based on panel regression linking long-term fundamentals to prices, as well as the relationship between price, rent and ownership cost implied by efficient markets. Using these measures to provide benchmarks for tracking market prices, we characterise price deviation in comparator countries, as well as discuss similarities and differences between China's experience and that seen elsewhere.

We have found that house prices were not significantly overvalued in China as a whole during the first half of 2010. However, the mass-market segment in a few large cities - such as Shanghai and Shenzhen, and the luxury segment in Beijing and Nanjing — do appear to be increasingly disconnected from fundamentals.

As home ownership increases, movements in aggregate household wealth and their potential impact on macroeconomic and financial stability will depend more on the extent of property price misalignment and the nature of the adjustment toward equilibrium. Over the past decade, house prices have corrected quickly in the cases of overall China, and in a few large Mainland cities; much like in the Hong Kong SAR and Singapore's private apartment markets. By and large, our indicators of price misalignment in China show less persistence than that was observed in advanced economies before 2008, especially the US, New Zealand, and France. In those cases, price misalignments persisted for a number of years and vulnerabilities were able to accumulate, ending in a large, abrupt adjustment in prices.

Despite its growing importance to the real economy, we find housing prices have had a somewhat limited impact on consumption. Nonetheless, its impact on private investment and local government revenue are sizable, particularly in cities that have high real estate investment. The growing importance of property in real activity and an increasing exposure of the banking sector to the real estate markets highlight the importance of using early warning measures of misalignment, like the one we develop, and the potential impacts will only grow over time. 
The Mainland Government's policy measures to cool down the markets unveiled in April 2010 appear to have had some impact on price growth. The gaps between market prices and fundamental based benchmarks have become smaller in a few cities in 2010 Q2. It is too early to say, however, whether the impact of such policies will turn out to be long lasting. Nevertheless, even if they are relatively effective against the recent surge in prices, such measures at best only treat the symptoms of high residential real estate inflation and not the underlying structural causes. To do that will require an increase in real interest rates, a higher carrying cost of home ownership (e.g. by imposing a broad-based property tax), and, in the case of China, broad financial market development to alternative investment vehicles to housing. 


\section{REFERENCES}

Dai, S., 2009, "Research on land finance and the usage of the land of local government," Journal of Fujian Normal University (Philosophy and Social Science Edition), No. 4, General No.157.

Fostel, A., and J. Geanakoplos, 2008, "Leverage cycles and the anxious economy," American Economic Review 98:4, pp. 1211-1244.

Geanakoplos, J., 2010, “The leverage cycle,” Cowles Foundation Discussion Paper No. 1715R, Yale University, New Haven, (January).

Geanakoplos, J., 2010, "Solving the present crisis and managing the leverage cycle," Cowles Foundation Discussion Paper No. 1751, Yale University, New Haven, (January).

Glindro, E. T, T. Subhanij, J. Szeto, and H. Zhu, 2008, "Determinants of house pries in nine Asia-Pacific economies," BIS Working Paper No.263.

Ha, J., and Z. Zhang, 2010, "The prospect of the Renminbi and its impact on various industries", China International Capital Corporation Ltd, Macroeconomic Report, 22 (March), in Chinese.

Harding, J., S. Rosenthal, and C. Sirmans, 2007, "Depreciation of housing capital, maintenance and house price inflation: Estimates from a repeat sales model," Journal of urban Economics, 61:2, (March), pp. 193-217.

He, D., W. Zhang, and J. Shek, 2007, "How efficient has been China's investment? Empirical evidence from national and provincial data," Pacific Economic Review, 12(5), 597-617.

Himmelberg, C., C. Mayer, and T. Sinai, 2005, "Assessing high house prices: Bubbles, fundamentals and misperceptions," Journal of Economic Perspective, 19:4, Fall, pp. 67-92.

Hong Kong Property Review, 2010, Rating and Valuation Department, the Government of Hong Kong SAR.

Hui, H., 2009, "The impact of property market developments on the real economy of Malaysia," International Research Journal of Finance and Economics, Issue 30. 
IMF, 2003, "When bubbles burst," in World Economic Outlook April 2003: Growth and Institutions, World Economic and Financial Surveys, International Monetary Fund, Chapter 2.

Leung, C., and L. Liu, 2005, "An empirical analysis of the fair value of Hong Kong's residential property prices," HKMA Research Memorandum.

Leung, F., K. Chow, and G. Han, 2008, "Long-term and short-term determinants of property prices in Hong Kong," the Hong Kong Monetary Authority Working Paper $15 / 2008$.

Meng, N., 2001, "Private residential property market and the macro-economy," Economic Survey of Singapore.

Peng, W., and J. Chang 2010, "Managing a property bubble," Barclays Capital, Emerging Markets Research.

Peng, W., and L. Cheung, 2001, "The property market and the macro-economy," HKMA Quarterly Bulletin.

Peng, W., D.C. Tam, and M.S. Yiu, 2008, "Property market and the macro-economy of Mainland China: A cross region study," Pacific Economic Review, V13 (2).

Poterba, J., 1984, "Tax subsidies to owner-occupied housing: An asset market approach," Quarterly Journal of Economics, 99:4, pp. 729-52.

Shin, H. S., 2009, "Discussion of 'The leverage cycle'," paper prepared for the 2009 NBER Macroeconomic Annual, (June).

Wang, Q., E. Ho, and S. Zhang, 2010, "Can recent policy campaign against property speculation cause a hard landing?" Morgan Stanley, Global Economic Forum.

Wu, J., J. Gyourko and Y. Deng (2010). "Evaluating conditions in major Chinese housing markets," NBER Working Paper 16189, National Bureau of Economic Research, MA., (July). 


\section{Appendix}

\section{Table A1: Property Market Related Policies in Mainland China ${ }^{20}$}

\section{Tightening measures}

Jan 2007 Impose value-added taxes on land transactions.

Sep 2007 Raise the minimum down-payment ratio to 40 per cent and the minimum mortgage rate to 110 per cent of the benchmark rate for second mortgage.

Minimum down-payment ratio and mortgage rates are higher for third mortgage loans.

Apr 2008 Impose tax on capital gains on advanced payments of housing purchases.

Jun 2008 Impose personal income taxes on corporate purchasing properties for individuals.

Aug 2008 Forbid loans for land purchases and for idle projects.

\section{Supportive policies}

Oct 2008 Waive stamp duty on housing transactions and value added taxes on land transactions.

Lower the minimum mortgages rate to 70 per cent of the benchmark rate and the down-payment ratio to 20 per cent.

Dec 2008 Extend preferential policies for first home purchases to second home purchases.

Shorten the housing holding period to enjoy business tax exemption from five years to two years.

May 2009 Reduce developers' capital requirement for economic and commodity housing investment to 20 per cent.

\section{Tightening measures}

Dec 2009 Extend the housing holding period to enjoy business tax exemption from two years to five years.

Require developers to pay at least 50 per cent as the initial payment for land purchase.

Jan 2010 Set minimum down-payment ratio for the second mortgages at 40 per cent.

Apr 2010 Raise minimum down-payment ratio for the first mortgage to 30 per cent for a residential property no more than 90 square metres.

Raise the down-payment ratio for the second mortgage to 50 per cent, and the minimum rate to 110 per cent of the benchmark rate.

The down-payment ratio and minimum mortgage rate for the third mortgage and above will be much higher.

-Restrict mortgage lending to non-residents

-Increase land supply for residential properties.

${ }^{20}$ Some tightening measures launched in September and October 2010 in national and city levels are not displayed in the table. Basically, these measures reinforce those introduced in April 2010. In addition, more than 10 major cities (i.e., Beijing, Shanghai, Hangzhou, Guangzhou, Shenzhen, Nanjing, Ningbo, Fuzhou, Xiamen, Tianjin, Haikou and Sanya) have set the upper limits of property units a household can purchase. 
Table A2: Description of data used in panel regression

\begin{tabular}{|c|c|c|}
\hline Series & Source & Data structure \\
\hline Real property price & NDRC, NBS, staff estimates & Nominal price deflated by city-specific CPI \\
\hline Real GDP & NBS, staff estimates & Nominal GDP deflated by city-specific CPI \\
\hline Real interest rate & PBOC, staff estimates & Nominal lending rate for over 5 years - national level inflation rate \\
\hline Land price index & NBS & $1998=100$ \\
\hline Population density & $\begin{array}{l}\text { NBS, } \\
\text { Local government website, } \\
\text { Staff estimates }\end{array}$ & $\begin{array}{l}\text { Resident population divided by the size of a city. } \\
\text { Subordinate prefectures and counties of a city but far way from the urban } \\
\text { area are excluded from the calculation. Owing to the annual population } \\
\text { data, density is the same for four quarters in the same year. }\end{array}$ \\
\hline Stock index & Shanghai Stock Exchange & \\
\hline Real final consumption & NBS & Nominal final consumption deflated by city-specific CPI \\
\hline Real fixed asset investment & NBS, staff estimates & $\begin{array}{l}\text { Fitted value obtained by regressing actaul real fixed asset investment } \\
\text { (FAl) on real gross capital formation (GCF), where real FAl and GCF are } \\
\text { obtained by deflating nominal FAl and nominal GCF by investment } \\
\text { deflator. }\end{array}$ \\
\hline Real cost of capital & $\begin{array}{l}\text { PBOC, NBS, } \\
\text { Staff estimates }\end{array}$ & $\begin{array}{l}\text { Real interest rates }+ \text { depreciation rate - growth rate differentials between } \\
\text { investment deflator and GDP deflator })^{*} \text { investment deflator relative to GDP } \\
\text { deflator/( } 1 \text { - tax rate). }\end{array}$ \\
\hline
\end{tabular}

Table A3: Sources of data used in the asset pricing approach

\begin{tabular}{lll}
\hline \multicolumn{1}{c}{ Data } & \multicolumn{1}{c}{ Source } \\
\hline 1. Industrial countries & \\
$\quad$ House price and rent & OECD \\
$\quad$ Income, interest rates, household size & CEIC \\
2. China & NDRC \\
$\quad$ Mass market, house price & Centaline \\
$\quad$ Mass market, rent & DTZ Property Research and NBS \\
$\quad$ Luxury segment, house price & DTZ Property Research and NBS \\
$\quad$ Luxury segment, rent & CEIC \\
$\quad$ Income, interest rates, household size & CEIC \\
3. Hong Kong SAR & Housing Department, Government of Hong Kong SAR \\
Private residential flat completion & CEIC \\
\hline
\end{tabular}

